\title{
OM SUBJEKTIVITET OG SANDHED I DEN GRESK-ROMERSKE ANTIK OG DEN TIDLIGE KRISTENDOM
}

Michel Foucault

About the Beginning of the Hermeneutics of the Self. Lectures at Darthmouth College 1980

The University of Chicago Press, 2016.

140 sider, $25 \$$

Den franske idéhistoriker Michel Foucault besøger i efteråret 1980 en række nordamerikanske universiteter for at give gæsteforelæsninger på engelsk om sin aktuelle forskning. I første omgang optræder Foucault med to forelæsninger på det offentlige University of California i Berkeley, og den efterfølgende diskussion med publikum bliver optaget på bånd. Derefter giver Foucault et interview på fransk omkring sin forskning til Michael Bess og afholder et seminar med Richard Sennett ved New York University. Til sidst gentager Foucault så de to oprindelige forelæsninger ved det private universitet Dartmouth College i New Hampshire, om end nu med nogle små ændringer og under en ny titel. University of Chicago Press har netop udgivet de to forelæsninger fra Darthmouth College sammen med den båndoptagede diskussion fra Berkeley og en oversættelse af interviewet med Michael Bess.

Foucaults besøg i USA følger umiddelbart efter hans forelæsningsrække $D u$ gouvernement des vivants ved Collége de France i begyndelsen af 1980. På dette tidspunkt har Foucault netop afdækket neoliberalismens og konkurrencestatsidéens fremkomst som en særegen regeringsform i forelæsningsrækken Biopolitikkens fødsel, og han er generelt interesseret i at undersøge, hvordan den vestlige subjektivitets historie er defineret ved et bestemt forhold til sandheden. Denne interesse har sådan set allerede fulgt Foucault fra hans arbejde med de to værker Overvågning og straf fra 1975 og Viljen til viden fra 1976, men i 1980 vender han for første gang sit fokus helt bort fra det moderne samfund for at undersøge antikkens etiske selvteknikker og selvpraksisser. For Foucault kommer denne vending for det første til at handle om at skrive subjektets genealogi, hvilket skal udgøre et teoretisk alternativ til modernitetens subjektfilosofi og dens forestilling om, at subjektet har en universel status. For det andet ønsker Foucault at benytte studiet af antikkens selvpraksisser som et afsæt for at kunne levere et mere nutidigt alternativ til konkurrencestatens regerings- og selvteknologier. 
De senere år har den intellektuelle og videnskabelige interesse for Foucaults arbejde især omfattet hans forelæsninger fra slutningen af 1970'erne om den moderne stat og såkaldte guvernementalitet. På mange måder er Foucaults studier af den oldgræske og romerske antik imidlertid langt mere visionær og fremsynet, og han foregriber i et vist omfang den nuværende genopblomstring af interessen for hellenismens og romertidens filosofiske livskunst. Foucaults studier trækker imidlertid også på en væsentlig inspiration fra Friedrich Nietzsches livsæstetik, og dermed på en forestilling om friheden som det enkelte menneskes selvskabelse. Dermed bliver Foucaults projekt i et vist omfang tilbageskuende og snævert knyttet til en særlig moderne opfattelse af mennesket, der ikke blot genfindes hos Nietzsche, men som også har en væsentlig lighed med den franske eksistentialisme. Som den franske filosofihistoriker Pierre Hadot påpeger, mangler Foucault en reel sans for den antikke filosofis spirituelle og selvoverskridende dimensioner, og derfor formår Foucaults projekt heller ikke at pege ud over hans egen samtid.

I forelæsningerne fra 1980 er Foucaults ærinde bundet op på en ambition om at levere en kritik af 'subjektets hermeneutik'. Det vil sige en bestemt selvteknologi, der er dybt indvævet i de moderne magtstrukturer og humanvidenskaber, og som indbefatter menneskets bestræbelse på at skabe positiv erkendelse og viden om sig selv som subjekt.

I den forbindelse følger forelæsningerne Foucaults velkendte strategi med at kontrastere forskellige tankesystemer, og på den baggrund kan han demonstrere, hvordan de hellenistiske og romerske selvteknologier ikke er bundet op på en tilsvarende hermeneutisk fortolkning af subjektets sandhed. Med udgangspunkt i den romerske filosof Lucius Annaeus Seneca viser Foucault, hvordan den stoiske selvpraksis består i en formning af det enkelte menneskes selv og livsførelse efter en i første omgang ydre sandhed. Med andre ord er den stoiske selvpraksis ikke baseret på en forestilling om, at den enkelte må opdage en skjult sandhed om sig selv og afsløre den til en anden. Det enkelte menneske indgår derimod i et forhold til en filosofisk mester, som bistår i at hjælpe ham eller hende med at skabe sig selv som et bestemt selv, ved at indarbejde den stoiske livsvisdom i sit forhold til sig selv. Dette mesterforhold har imidlertid kun en foreløbig karakter, og målet er, at den enkelte lærer kunsten at leve et godt liv på en selvstændig og uafhængig måde.

Foucault påviser dels, hvordan de stoiske selvteknologier dermed adskiller sig væsentligt fra de gnostiske og buddhistiske selvpraksisser, hvor den enkelte må op- 
dage den indre sandhed med sig selv for at opnå en åndelig oplysning. Dels demonstrerer Foucault, hvordan den hermeneutiske selvpraksis får en mere selvstændig betydning i de kristne klostre, hvor den bliver til en bekendelsespraksis, der antager to forskellige, om end beslægtede, former.

For det første giver Foucault et indblik i den kristne bodspraksis, som er baseret på en dramatisk selvafsløring. Således kan et syndigt klostermedlem undgå udvisning fra kirken ved at angre sine synder offentligt igennem et langstrakt bodsritual. Herunder må den syndige udvise en villighed til at dø som synder og få et nyt åndeligt liv. Således er den kristne bodspraksis baseret på en bestemt selvteknologi, exomologesis, hvor den angrende giver afkald på sit eget ego igennem et særligt martyrium og dermed afdør fra sig eget syndige selv.

For det andet omfatter klosterlivet en anden bekendelsespraksis, exagoreusis, hvor den enkelte munk må indgå i en vedvarende analysering og verbalisering af sine egne tanker. Munkelivet involverer dermed en særlig form for lydighed og underkastelse, som adskiller sig væsentligt fra det stoiske mesterforhold, idet munken må adlyde sin åndeligt overordnedes vilje i et og alt. Det går munken gennem en vedvarende udforskning af sine tanker, sådan at munken kan bekende dem til sin overordnede, med henblik på at gøre sin sjæl og sit hjerte så rent som muligt over for Gud. Som Foucault demonstrerer, er denne bekendelsespraksis også baseret på en ambition om at udrydde den enkelte munks ego, sådan at han kan undvige Satan og opnå en åndelig oplysning. Dermed adskiller den kristne bekendelsespraksis sig imidlertid også væsentligt fra de moderne selvteknologier og humanvidenskaber. Her er målet ikke er at opdage sandheden om selvet for at udrydde det. Målet er derimod at afdække en sandhed om selvet, der kan fungere som et positivt grundlag for magtteknologier.

I bogens interview med Bess og den afsluttende diskussion får Foucault trukket nogle tråde til hans tanker om etik og politik i vores tid. Blandt andet viser han, hvordan vor tids forestillinger om subjektets hermeneutik er indvævet i selvteknologier, der er dybt forankrede i det moderne samfunds magtstrukturer og politiske regering. Foucault opfatter sig selv som en slags moralist, og af samme grund peger han på vigtigheden af at opgive vores trang til at søge sandheden om selvet inden for humanvidenskaberne og -teknologierne. Det moderne menneskes mulighed for egentlig frihed er betinget af, at det yder modstand imod disse sandheder og $\mathrm{i}$ stedet opdyrker en nysgerrighed over for tilværelsen og innovativ evne til at tænke 
og handle på stadig nye måder. Derfor undviger hans projekt også enhver bestræbelse på at fortælle folk, hvad der egentlig er det rigtige for dem at gøre i livet. Det gode kan i det hele taget slet ikke defineres af enkeltpersoner, men må til stadighed opfindes og skabes igennem kollektive praksisser.

Anders Draby Sørensen 